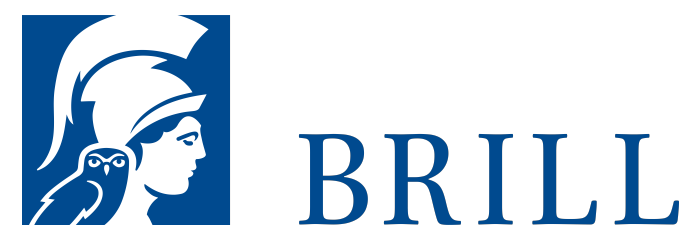

\title{
Die Kunst des Verschiebens
}

\section{Dekonstruktion für Einsteiger}

Author: Robert Feustel

Dekonstruktion ist in aller Munde - entweder als konturloser Pop oder harter, akademischer Brocken. Was steckt hinter diesem widersprüchlichen Begriff? Und lässt er sich »unphilosophisch« erklären? Einerseits ist Dekonstruktion eine Allerweltsvokabel im Feuilleton und im bildungsbürgerlichen Kulturgut. Andererseits ist sie ein hoch theoretisches Werkzeug in den Gemäuern altehrwürdiger Universitäten, vom Charme des Unverständlichen umhüllt. Das Buch versucht, sowohl die zeitgenössische Popularität und Verwässerung als auch die akademische Komplexität zu vermeiden. Stattdessen wird Derridas Wortschöpfung als Perspektive oder Haltung anhand von Beispielen und möglichst ohne den Pomp philosophischer Begriffe vorgestellt. Übrig bleibt eine Denkbewegung, die nicht zu Unrecht für Aufsehen gesorgt hat und dennoch sehr spezifisch ist. Letztlich ist sie vor allem eines: politisch.

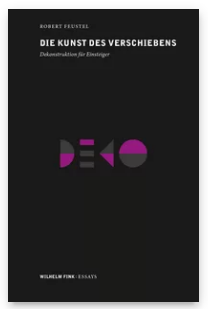

Pages: 120 Seiten Language:

German

Subjects: 19 th \& 2oth Century

Philosophy, Philosophy

Publisher: Brill | Fink

Series:

Wilhelm Fink:

Essays

E-Book (PDF)

Released online:

12 Jun 2015

ISBN: 978-3-

8467-0003-7

List price

Paperback

Publication date:

23 Mar 2015

ISBN: 978-3-

7705-5857-5

List price 
Robert Feustel studierte bis 2006 Politikwissenschaft und Geschichte in Leipzig und Madrid. Er promovierte zum Thema „Grenzgänge. Kulturen des Rauschs seit der Renaissance“ im Jahr 2012. Seitdem ist er wissenschaftlicher Mitarbeiter an der Universität Leipzig.

For more information see brill.com

Order information: Order online at brill.com +44330 3330049 | customerservices@brill.com Submission information: brill.com/authors

Titles published by Brill | Fink, Brill | mentis or Brill | Schöningh: +49(o)71 5413279216 | brill@brocom.de 